\title{
Water Quality Monitoring Using Biological Indicators in Cameron Highlands Malaysia
}

\author{
Kok Weng $\operatorname{Tan}^{1} \&$ Weng Chee Beh ${ }^{2}$ \\ ${ }^{1}$ Faculty of Engineering and Green Technology, Universiti Tunku Abdul Rahman, Malaysia \\ ${ }^{2}$ Faculty of Science and Technology, Universiti Kebangsaan Malaysia, Malaysia \\ Correspondence: Tan Kok Weng, Faculty of Engineering and Green Technology, Universiti Tunku Abdul \\ Rahman, Jln Universiti, Bdr. Barat, 31900 Kampar Perak Malaysia, Malaysia. E-mail: tankokweng@utar.edu.my
}

Received: January 21, 2015 Accepted: April 3, 2015 Online Published: May 7, 2015

doi:10.5539/jsd.v8n3p28

URL: http://dx.doi.org/10.5539/jsd.v8n3p28

\begin{abstract}
Macroinvertebrates are easily available, identified and have been used as bio-monitoring agent successfully. It is useful in detecting transient and longtime pollution to our aquatic system. The aim of this study was to determine the relationship between river water quality and the macroinvertebrates organism in the stream. Pauh River in Cameron Highlands, Malaysia has been chosen for this study. A total of six monitoring stations along Pauh River were setup in this study. In-situ field investigation and water sampling was conducted. Malaysian's Water Quality Index (WQI) for the 6 sampling stations are calculated and compared with the macroinvertebrates sample. The pattern of distribution and abundance of different macroinvertebrates which correspond to polluted and non-polluted parts of each river studied suggested macroinvertebrates could be used as potential indicators for bio-monitoring in Malaysia.
\end{abstract}

Keywords: bio-indicator, water quality monitoring, macro-invertebrate, Cameron Highlands

\section{Introduction}

Human activities have severely affected the condition of freshwater ecosystems worldwide. Physical alteration, habitat loss, water withdrawal, pollution, overexploitation and the introduction of non-native species all contribute to the decline in freshwater species and the water quality as well. Increasing human population growth and achieving sustainable development targets place even higher demand on the already stressed freshwater ecosystems. Water quality is a measurement to determine the pollution level that happens in water (Karanth, 1987), showing the reaction in water composition towards all the input whether is natural or manmade (Krenkel \& Novotny, 1980). However, physical and chemical monitoring instruments are usually expensive and can only be used at limited number of sites thus unable to achieve distribution patterns (Swaminathan, 2003). Hence, biological monitoring is considered one of alternatives which useful and rapid assessment tool to check the status of water quality.

Biological monitoring (also called bio-monitoring or bio-assessment) is defined as an evaluation of the condition of a water body using biological surveys and other direct measurements of the resident biota in surface waters (Engel \& Voshell, 2002) for example plants and animals or its components to provide continuous analytical information (Kopciuh et al., 2004). Biological monitoring can be done with any living organisms (biological indicators) but benthic macroinvetebrate, fish, and periphyton (algal) assemblages are used more often, in that order (Engel \& Voshell, 2002). Those biological indicators describing the condition and threats to freshwater ecosystems are required to measure progress in halting the rapid decline in freshwater species (Revenga et al., 2005). Tolerance of bio-indicator organism usually have its limit, therefore the presence or absence and its health state can determine some of the chemical and physical components in the environment without the complex measurement and laboratory work (Kopciuh et al. 2004). Changes in benthic macroinvertebrates community with water pollution have many been documented and measured using different aspects including biomass, species density and species composition (Yong et al., 1997).

Bentic macroinvertebrates are those organisms that live on the bottom of aquatic environments, or on objects protruding above the bottom, and are large enough to see by eye without any magnification. Benthic macroinvertebrates are used most often based on several reasons. First, macroinvertebrates do not migrate in a 
short term period, thereby ensuring exposure to a pollutant or stress reliably conveys local condition. This reliable presentation of ecological condition allows for comparison of sites that are in close proximity. Second, macroinvertebrates life stages are short enough that sensitive life stages will be affected by stress, but long enough that any impairment is measureable in the assemblage. Macroinvertebrates are found in even the smallest streams and have a wide range of sensitivity to all types of pollution and stress, allowing for monitoring in most conditions. Finally, sampling macroinvertebrates is easy, cost effective, and does not permanently harm the local assemblage (Engel \& Voshell, 2002; Kusza, 2005). Impairment can be easily be detected by the trained monitor with even the simplest of identifications (Engel \& Voshell, 2002). Hamed et al., (2014) states that more species distribution indicated (i.e. the number of individual organisms or abundance of species) are more similar the level of stability of biodiversity in the area. This distribution of species can be determined by different types of bio-indices e.g. Shannon Diversity Index, Margalef Diversity index and etc. Different types of studies have been conducted on the relationship of water quality and bio-indices i.e. Hamed et al., (2014), Azrina et al. (2006); Ogleni and Topal (2011); Nemati et al. (2010); Latha and Thang (2010). However, lacks of studies are carried out in highland region. Thus, the aim of this study is to determine the relationship between river water quality and the distribution of benthic macroinvertebrates organism in the Cameron Highlands.

\section{Study Area}

Cameron Highlands is a well-known tourism destination and agricultural place of Malaysia, but also an environmentally-sensitive area (Wan Abdullah et al., 2005; Gasim et al., 2009). It is situated in the Pahang State and has an estimated area of $712 \mathrm{~km}^{2}$. It is located on the Main Range of Peninsular Malaysia between $4^{\circ} 20^{\prime} \mathrm{N}-4^{\circ} 37^{\prime} \mathrm{N}$ and $101^{\circ} 20^{\prime}-101^{\circ} 36^{\prime} \mathrm{E}$ (Figure 1), which is made up of three major sub-district of Telom, Ringlet and Tanah Rata. The altitude is between 1,280 m and 1,830 m above sea level (Ngan et al., 2005; Gasim et al., 2009). Due to highland characteristics, Cameron Highlands has average daily temperature is about $14^{\circ} \mathrm{C}$ to $21^{\circ} \mathrm{C}$ and annual rainfall is $2,800 \mathrm{~mm}$ (Ismail et al., 2004; Gasim et al., 2009). With these unique characteristics, agricultural cultivation becomes the main human activity in Cameron Highlands. Besides the contribution of national GDP by exporting agricultural products i.e. vegetable and flower, unsustainable agricultural practices also have been recognised as main pollution sources to water quality in this area (Tan, 2012).

Three main rivers have been identified in Cameron Highlands namely Bertam River, Telom River and Lemoi River. An estimated 5.8 million litres per day (MLD) of water is abstracted at several intake points from rivers originating from mountain forests in Cameron Highlands for water supply and irrigation purpose (Kumaran, S., and Ainuddin, 2006). Pauh River is one of tributaries for Bertam River. According to Dinakaran \& Anbalagan (2007), Pauh River was identified as one of important recreational place for both local and international tourist.

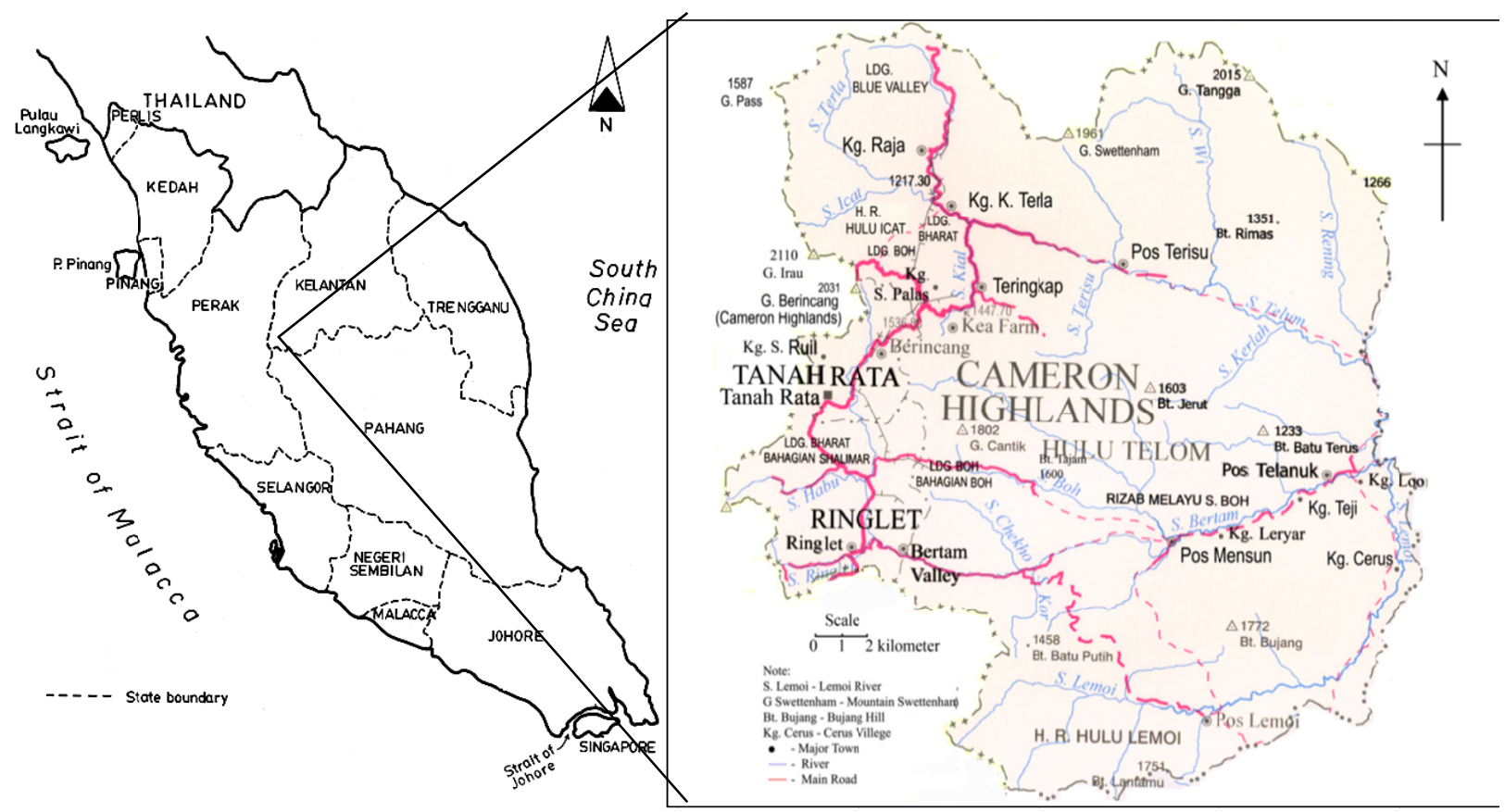

Figure 1. Location of Cameron Highlands in Malaysia

Source: Edited from FAO; Department of Survey and Mapping, 2002 


\section{Experimental Details}

Total six sampling stations were set up for this study which representing upstream and downstream of Pauh River. Location of sampling stations had been shown in Table 1 Water quality and macroinvertebrates organism samplings were done once every 2 months throughout the year of 2013. The geographical records of the sampling site were taken using Global Positioning System (GPS). Hydrological and ecological information such as substrate composition, sunlight exposure, width, depth, stream flow and general description of the sampling site was noted by field investigation.

Table 1. Characteristics of monitoring stations in Pauh River, Cameron Highlands

\begin{tabular}{|c|c|c|c|c|c|c|}
\hline Sampling stations & 1 & 2 & 3 & 4 & 5 & 6 \\
\hline \multirow{4}{*}{ Location } & $\begin{array}{lll}\mathrm{N}^{\prime} & \mathrm{O}^{\circ} & 28^{\prime}\end{array}$ & $\begin{array}{lll}\mathrm{N} & 04^{\circ} \quad 28^{\prime}\end{array}$ & $\mathrm{N} \quad 04^{\circ} \quad 28^{\prime}$ & $\begin{array}{lll}\mathrm{N} & 04^{\circ} & 28^{\prime}\end{array}$ & $\begin{array}{lll}\mathrm{N} & 04^{\circ} & 28^{\prime}\end{array}$ & $\mathrm{N} 04^{\circ} 28^{\prime} 45^{\prime \prime}$ \\
\hline & $47 "$ & $48.4 "$ & $6.3^{\prime}$ & $6.3^{\prime \prime}$ & $45^{\prime \prime}$ & \\
\hline & E $101^{\circ} 23^{\prime}$ & E $101^{\circ} 23^{\prime}$ & E $101^{\circ} 23^{\prime}$ & E $101^{\circ} 22^{\prime}$ & E $101^{\circ} 22^{\prime}$ & E $101^{\circ} \quad 22^{\prime}$ \\
\hline & $6.4^{\prime \prime}$ & $7.5^{\prime \prime}$ & $1.8^{\prime \prime}$ & $59.1 "$ & $57.9^{\prime \prime}$ & $57.06^{\prime \prime}$ \\
\hline Elevation (m) & 1477 & 1449 & 1501 & 1463 & 1451 & 1468 \\
\hline River length (m) & 3.3 & 3.4 & 1.5 & 1.7 & 2.0 & 6.7 \\
\hline $\begin{array}{l}\text { River depth }(\mathrm{m}) \\
\text { stream flow }\left(\mathrm{ms}^{-1}\right)\end{array}$ & 0.16 & 0.18 & 0.14 & 0.16 & 0.15 & 0.32 \\
\hline Vegetation (\%) & 90 & 80 & 60 & 20 & 30 & 10 \\
\hline Subtract & & & & & & \\
\hline compositions & 80 & 60 & 50 & 50 & 40 & 20 \\
\hline Rock & 15 & 30 & 40 & 30 & 40 & 30 \\
\hline $\begin{array}{l}\text { Sand } \\
\text { Mud }\end{array}$ & 5 & 10 & 10 & 20 & 20 & 50 \\
\hline
\end{tabular}

\subsection{Water Sampling and Analysis}

Measurement of temperature, $\mathrm{pH}$, dissolved oxygen (DO), conductivity and total dissolved solid was conducted during field investigation by using multi-parameters YSI 556 MPS (APHA, 1992; APHA, 1998). All these parameters were measured $0.1 \mathrm{~m}$ from the water surface because at this depth, the content of the stream water are mixing well. Water sample for detection of biological oxygen demand (BOD), chemical oxygen demand (COD), ammoniacal-nitrogen $\left(\mathrm{NH}_{3}-\mathrm{N}\right)$ and total suspended solid (TSS) are taken and analyzed by referring the standard method of APHA 1998. Water Quality Index (WQI) was calculated based on the formula developed by the Department of Environmental, Malaysia (DOE, 2007).

\subsection{Macroinvertebrates}

Macroinvertebrates sampling was done on Pauh River bank. Surber net was used for macroinvertebrates sampling. Larger debris such as leaves, twigs, rocks and plants were removed and the macroinvertebrates organisms were kept using zipper plastic bag. The procedure had been repeated 10 times at the same station with different locations of the site. Samples were preserved with $70 \%$ ethanol and kept in fridge as specimen. Four bio-indices i.e Shannon Diversity Index, Margalef Diversity index and Pielou equality index, Average Score per Taxon (ASPT) and biological monitoring working party (BMWP) were selected in this study to describe the distribution of the communities of species.

\subsection{Statistical Analysis}

From the data that was collected throughout the year 2013, correlation test between Water Quality Index (WQI) and benthic macroinvertebrates organism was applied using statically method with SPSS 16 software. One-Way analysis of variance (ANOVA) and Tukey test were applied to identify the significant differences among station $1,2,3,4$ and 5. Besides, Pearson correlation analysis was carried out to determine the relationship between WQI and Bio-indices. 


\section{Results and Discussion}

\subsection{Water Quality Index (WQI)}

In order to calculate Pauh River WQI, six parameters have been used namely $\mathrm{pH}$, dissolved oxygen (DO), chemical oxygen demand (COD), biological oxygen demand (BOD), Total suspended solid (TSS) and ammoniacal-nitrogen $\left(\mathrm{NH}_{3}-\mathrm{N}\right)$. Table 2 shows the analysis results for 6 stations of the parameters measured. By comparing to National Water Quality Standards for Malaysia (NWQS) (Table 3), DO, pH and TSS at 6 monitoring station were in Class II. BOD, $\mathrm{COD}$ and $\mathrm{NH}_{3}-\mathrm{N}$ in Station 6 was recorded in Class III that is polluted status.

Statistical analysis does not indicate significant difference between sampling months of February for Pauh River $(P>0.05)$. As shown in Figure 2, water quality class II (Station 1-5) requires conventional treatment and suitable for sensitive aquatic species and recreational activities that involve bodily contact. Water quality class III (Station 6) requires extensive treatment and suitable for fish farming economic value of tolerance as well as serve as a source of drinking water for livestock.

Table 2. Average of Six WQI parameters for Pauh River, Cameron Highlands

\begin{tabular}{lllllll}
\hline Parameters & Station 1 & Station 2 & Station 3 & Station 4 & Station 5 & Station 6 \\
\hline $\mathrm{DO}(\mathrm{mg} / \mathrm{l})$ & 7.14 & 7.09 & 6.98 & 7.11 & 7.13 & 5.60 \\
$\mathrm{COD}(\mathrm{mg} / \mathrm{l})$ & 16.11 & 22.71 & 22.52 & 20.43 & 35.94 & 46.81 \\
$\mathrm{BOD}(\mathrm{mg} / \mathrm{l})$ & 2.17 & 2.16 & 2.47 & 3.07 & 2.43 & 5.10 \\
$\mathrm{NH}_{3}-\mathrm{N}(\mathrm{mg} / \mathrm{l})$ & 0.13 & 0.12 & 0.12 & 0.12 & 0.15 & 0.75 \\
$\mathrm{pH}$ & 6.10 & 6.22 & 6.20 & 6.20 & 6.28 & 6.14 \\
$\mathrm{TSS}(\mathrm{mg} / \mathrm{l})$ & 0.20 & 0.02 & 0.03 & 0.01 & 0.02 & 0.03 \\
\hline
\end{tabular}

Table 3. National water quality standards for Malaysia

\begin{tabular}{|c|c|c|c|c|c|c|c|}
\hline & DA D & INUT & & & CLASS & & \\
\hline & ГАNAVIL ILN & ONII & I & II & III & IV & $\mathrm{V}$ \\
\hline Ammonia & cal Nitrogen & $\mathrm{mg} / \mathrm{l}$ & $<0.1$ & $0.1-0.3$ & $0.3-0.9$ & $0.9-2.7$ & $>2.7$ \\
\hline Biochemi & cal Oxygen Demand & $\mathrm{mg} / \mathrm{l}$ & $<1$ & $1-3$ & $3-6$ & $6-12$ & $>12$ \\
\hline Chemical & Oxygen Demand & $\mathrm{mg} / \mathrm{l}$ & $<10$ & $10-25$ & $25-50$ & $50-100$ & $>100$ \\
\hline Dissolved & Oxygen & $\mathrm{mg} / \mathrm{l}$ & $>7$ & $5-7$ & $3-5$ & $1-3$ & $<1$ \\
\hline $\mathrm{pH}$ & & - & $>7$ & $6-7$ & $5-6$ & $<5$ & $>5$ \\
\hline Total Sus & pended Solid & $\mathrm{mg} / \mathrm{l}$ & $<25$ & $25-50$ & $50-150$ & $150-300$ & $>300$ \\
\hline Water Qu & ality Index (WQI) & - & $<92.7$ & $76.5-92.7$ & $51.9-76.5$ & $31.0-51.9$ & $>31$ \\
\hline Class I & $\begin{array}{l}\text { Conservation of natu } \\
\text { Water Supply I - Pra } \\
\text { Fishery I - Very sens }\end{array}$ & $\begin{array}{l}\text { onment. } \\
\text { lo treatm } \\
\text { atic spec }\end{array}$ & $\begin{array}{l}\text { ent necess } \\
\text { les. }\end{array}$ & & & & \\
\hline Class IIA & $\begin{array}{l}\text { Water Supply I } \\
\text { Fishery II - Sen }\end{array}$ & uatic spe & $\begin{array}{l}\text { reatment. } \\
\text { cies. }\end{array}$ & & & & \\
\hline Class IIB & Recreational us & ontact. & & & & & \\
\hline Class III & $\begin{array}{l}\text { Water Supply III - E } \\
\text { Fishery III - Comm }\end{array}$ & $\begin{array}{l}\text { treatmer } \\
\text { nomic } \mathrm{v}\end{array}$ & $\begin{array}{l}\text { trequired } \\
\text { lue and to }\end{array}$ & erant species & vestock drin & & \\
\hline $\begin{array}{l}\text { Class IV } \\
\text { Class V }\end{array}$ & $\begin{array}{l}\text { Irrigation } \\
\text { None of the above. }\end{array}$ & & & & & & \\
\hline
\end{tabular}

Source: DOE, 2007 


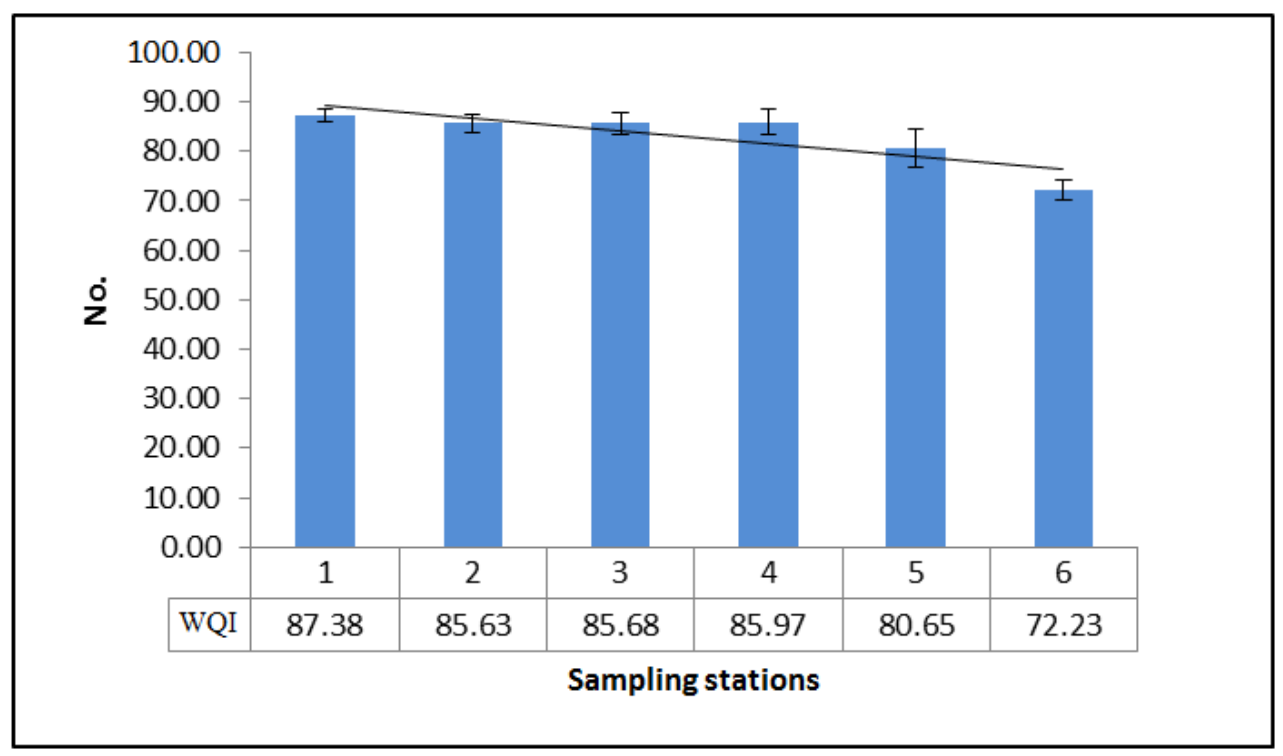

Figure 2. Average of water quality index (WQI) for six monitoring stations

\subsection{Distribution of Benthic Macroinvertebrates by Location (Spatial)}

Table 4 shows the abundance of macroinvertebrates expresses as percentage of total found from each sampling period. The macroinvertebrates found were from the groups of Coleoptera, Trichoptera, Hemiptera, Ephemeroptera, Plecoptera, Diptera, Odonata, Gastropoda, Hirudinea and Oligochaeta. A total of 51 families (taxa) were identified from the sampling sites during the sampling period. Most abundant family was recorded on June and August. There are 34 taxa found in both month. Most least taxa was recorded on February. There are 25 taxa found on February. . The lack of obvious difference in the presence or absence of the macroinvertebrates taxa during the alternate monthly samplings indicated macroinvertebrates communities in Pauh River was not fluctuating and total $90 \%$ of the macroinvertebrates could be consistently found in the sampling site. 
Table 4. Macroinvertebrates abundance, as percentage (expressed of total in a month period) found at the Pauh River, Cameron Highlands

\begin{tabular}{|c|c|c|c|c|c|c|c|c|}
\hline \multirow[b]{2}{*}{ Phylum } & \multirow[b]{2}{*}{ Class } & \multirow[b]{2}{*}{ Order } & \multirow[b]{2}{*}{ Family } & \multicolumn{5}{|c|}{$\mathrm{ind} / \mathrm{m}^{2}$} \\
\hline & & & & Feb & Apr & Jun & Aug & Oct \\
\hline \multirow[t]{7}{*}{ Arthropoda } & \multirow[t]{7}{*}{ Insecta } & \multirow[t]{7}{*}{ Coleoptera } & Elmidae & 0.88 & 3.75 & 17.71 & 16.98 & 26.56 \\
\hline & & & Psephenidae & 0.75 & 0.94 & 1.25 & 2.40 & 4.58 \\
\hline & & & Sperchidae & 0.75 & 0.21 & 0.63 & 0.83 & 1.56 \\
\hline & & & Hydrophilidae & 0.13 & 3.65 & 1.98 & 1.04 & 1.04 \\
\hline & & & Dryopidae & 2.38 & 1.35 & 1.56 & 4.48 & 0.21 \\
\hline & & & Eulichalidae & 0.25 & 0.31 & 0.31 & 0.21 & 0.42 \\
\hline & & & Scirtidae & - & 0.31 & 0.42 & 2.60 & 0.83 \\
\hline \multirow[t]{2}{*}{ Arthropoda } & \multirow[t]{2}{*}{ Insecta } & \multirow[t]{2}{*}{ Hemiptera } & Aphelocheiridae & 1.63 & 1.46 & 3.23 & 1.77 & 3.65 \\
\hline & & & Mesoveliidae & 0.88 & 0.42 & 0.21 & 0.73 & 0.31 \\
\hline \multirow[t]{3}{*}{ Arthropoda } & \multirow[t]{3}{*}{ Insecta } & \multirow[t]{3}{*}{ Plecoptera } & Perlidae & 12.88 & 23.44 & 25.31 & 32.92 & 46.98 \\
\hline & & & Peltoperlidae & 0.63 & 0.31 & 0.42 & 0.52 & 0.52 \\
\hline & & & Nemouridae & 3.25 & 3.54 & 5.21 & 3.75 & 8.54 \\
\hline \multirow[t]{3}{*}{ Arthropoda } & \multirow[t]{3}{*}{ Insecta } & \multirow[t]{3}{*}{ Ephmeroptera } & Baetidae & 2.13 & 25.21 & 32.50 & 25.42 & 30.31 \\
\hline & & & Heptageniidae & 3.25 & 8.65 & 10.31 & 8.23 & 10.00 \\
\hline & & & Leptophlebiidae & - & 1.56 & 4.48 & 4.90 & 2.50 \\
\hline \multirow[t]{5}{*}{ Arthropoda } & \multirow[t]{5}{*}{ Insecta } & \multirow[t]{5}{*}{ Trichoptera } & Hydropsychidae & 4.25 & 14.27 & 19.58 & 16.46 & 23.02 \\
\hline & & & Leptoceridae & 1.00 & 5.73 & 1.04 & 0.42 & 8.54 \\
\hline & & & Lepistomadidae & 3.50 & 4.48 & 7.40 & 10.42 & - \\
\hline & & & Polycentropodidae & 0.50 & 2.81 & 3.33 & 4.27 & 3.44 \\
\hline & & & Philopotamidae & 0.38 & 1.56 & 4.17 & 7.60 & 1.25 \\
\hline \multirow[t]{2}{*}{ Arthropoda } & \multirow[t]{2}{*}{ Insecta } & \multirow[t]{2}{*}{ Odonata } & Libellulidae & 1.13 & 1.67 & 0.63 & 1.35 & 1.46 \\
\hline & & & Gomphidae & 0.63 & - & - & - & \\
\hline \multirow[t]{5}{*}{ Arthropoda } & \multirow[t]{5}{*}{ Insecta } & \multirow[t]{5}{*}{ Diptera } & Tipulidae & 0.63 & 1.04 & 3.44 & 2.19 & 4.90 \\
\hline & & & Simuliidae & 10.25 & 28.02 & 22.81 & 63.54 & 63.44 \\
\hline & & & Chironomidae & 16.38 & 60.52 & 484.48 & 409.69 & 256.98 \\
\hline & & & Ceraptopogonidae & - & 1.56 & 3.13 & 3.33 & 1.25 \\
\hline & & & Athericidae & - & 0.10 & 0.10 & 0.73 & 0.21 \\
\hline Arthropoda & Malacostraca & Decapoda & Sesarmidae & 0.50 & 0.31 & 0.31 & 0.42 & 0.63 \\
\hline Mollusca & Gastropoda & Neogastropod & Planorbidae & - & - & 1.46 & 1.15 & 0.21 \\
\hline & & & Physidae & 0.13 & 20.42 & 27.40 & 9.58 & 10.42 \\
\hline Annelida & Oligochaeta & Opisthopora & Tubificidae & - & 0.10 & 19.69 & 3.85 & 59.90 \\
\hline & & & Lumbriculidae & - & 0.31 & 0.42 & 0.63 & 1.04 \\
\hline & & & Naididae & - & 0.10 & - & 0.21 & 0.31 \\
\hline Annelida & Hirudinea & Gnathobdellida & Erpobdellidae & - & 1.67 & 6.77 & 2.08 & 9.48 \\
\hline Platyheminthes & Turbellaria & Seriata & Dugesiidae & - & 1.35 & 1.46 & 0.63 & - \\
\hline & & & Total & 69.00 & 221.15 & 713.13 & 645.31 & 584.48 \\
\hline
\end{tabular}

Table 5 shows the distribution and average density of phylogenetic benthic macroinvertebrate fauna for each monitoring station according to Phylum, Class, Order and Family. Total 28 to 31 taxa have been found in Station 1, 2, 3, 4 and 5 (upstream to middle stream). However, only 7 taxa found in Station 6 (downstream). Station 4 
was recorded with 31 taxa with an average density $368.28 \mathrm{ind} / \mathrm{m}^{2}$ which is the highest number of distribution of taxa among the monitoring stations. According to WQI analysis result, Station 4 has recorded Class II, which is suitable for sensitive aquatic species. This may be the reason of abundance of macroinvertebrates found in this location. Station 6 has the lowest number of taxa which is 7 taxa; however it has recorded highest density of $680.15 \mathrm{ind} / \mathrm{m}^{2}$. High density is contributed by Chironomidae, Tubificidae and Physidae.

The abundance of Diptera; Chironomiidae and Simuliidae in Pauh river indicated organic pollution (Buckup et al. 2007; Kusza 2005), which is true due to the recreational function of the river. There was a camping site located at the Pauh River. The river is polluted with domestic waste throw by the camper especially foods waste and detergent used to wash off their culinary sets.

Table 6 shows the average value of biological index according to monitoring stations. Overall, the Shannon Diversity Index, Margalef Diversity index and Pielou equality index, Average Score per Taxon (ASPT) and biological monitoring working party (BMWP) have been decreased from station 1 to station 6 . As mentioned, it was due to decrease of water quality index from Class II to Class III.

Table 5. Distribution and average density of phylogenetic macroinvertebrate fauna

\begin{tabular}{|c|c|c|c|c|c|c|c|c|c|}
\hline \multirow[b]{2}{*}{ Filium } & \multirow[b]{2}{*}{ Class } & \multirow[b]{2}{*}{ Order } & \multirow[b]{2}{*}{ Famili } & \multicolumn{6}{|c|}{ (ind $/ \mathrm{m}^{2}$ ) } \\
\hline & & & & Station 1 & Station 2 & Station 3 & Station 4 & Station 5 & Station 6 \\
\hline \multirow[t]{7}{*}{ Arthropoda } & Insecta & Coleoptera & Elmidae & 7.71 & 7.81 & 8.13 & 19.48 & 22.61 & - \\
\hline & & & Psephenidae & 4.06 & 2.19 & 1.98 & 0.73 & 0.83 & - \\
\hline & & & Sperchidae & 1.15 & 0.73 & 0.938 & 0.83 & 0.31 & - \\
\hline & & & Hydrophilidae & 1.25 & 1.36 & 1.56 & 1.15 & 2.50 & - \\
\hline & & & Dryopidae & 5.73 & 1.36 & 1.56 & 1.15 & 2.50 & - \\
\hline & & & Eulichalidae & 0.21 & - & 0.52 & 0.52 & 0.21 & - \\
\hline & & & Scirtidae & 0.73 & 0.32 & 0.21 & 1.36 & 1.56 & - \\
\hline \multirow[t]{2}{*}{ Arthropoda } & Insecta & Hemiptera & Aphelocheiridae & 1.98 & 0.73 & 1.36 & 5.94 & 1.46 & - \\
\hline & & & Mesoveliidae & 0.52 & 0.42 & 0.63 & 0.83 & 0.11 & - \\
\hline \multirow[t]{3}{*}{ Arthropoda } & Insecta & Plecopetera & Perlidae & 38.23 & 38.86 & 26.88 & 19.38 & 12.08 & - \\
\hline & & & Peltoperlidae & 0.94 & 0.21 & 0.11 & 0.94 & 0.11 & - \\
\hline & & & Nemouridae & 3.86 & 2.29 & 3.65 & 6.98 & 6.98 & - \\
\hline \multirow[t]{3}{*}{ Arthropoda } & Insecta & Ephemeroptera & Baetidae & 18.86 & 27.08 & 28.33 & 28.86 & 10.11 & 2.38 \\
\hline & & & Heptageniidae & 10.63 & 11.77 & 10.42 & 3.65 & 3.02 & - \\
\hline & & & Leptophlebiidae & 5.11 & 2.40 & 3.02 & 2.71 & 0.42 & - \\
\hline \multirow[t]{5}{*}{ Arthropoda } & Insecta & Trichopetra & Hydropsychidae & 12.08 & 5.31 & 13.86 & 22.81 & 22.81 & - \\
\hline & & & Leptoceridae & 7.40 & 4.38 & 1.56 & 2.92 & 0.31 & - \\
\hline & & & Lepistomadidae & 6.77 & 7.08 & 1.25 & 1.67 & 5.52 & - \\
\hline & & & Polycentropodidae & 5.00 & 2.61 & 4.90 & 1.04 & 0.73 & - \\
\hline & & & Philopotamidae & 8.65 & 4.48 & 0.73 & 0.52 & 0.52 & - \\
\hline \multirow[t]{2}{*}{ Arthropoda } & Insecta & Odonata & Libellulidae & 0.83 & 1.56 & 2.40 & 0.94 & 0.63 & - \\
\hline & & & Gomphidae & 0.42 & 0.11 & - & - & - & - \\
\hline \multirow[t]{5}{*}{ Arthropoda } & Insecta & Diptera & Tipulidae & 4.58 & 1.88 & 1.46 & 1.98 & 2.19 & - \\
\hline & & & Simuliidae & 48.54 & 66.67 & 56.36 & 4.69 & 4.27 & - \\
\hline & & & Chironomidae & 51.25 & 68.65 & 206.98 & 231.04 & 230.52 & 466.75 \\
\hline & & & Ceraptopogonidae & 1.67 & 2.08 & 1.25 & 2.71 & 1.88 & - \\
\hline & & & Athericidae & 0.21 & 0.11 & 0.42 & 0.42 & - & - \\
\hline
\end{tabular}




\begin{tabular}{|c|c|c|c|c|c|c|c|c|c|}
\hline Arthropoda & Malacostraca & Decapoda & Sesarmidae & 0.83 & 0.11 & 0.42 & 0.42 & - & - \\
\hline \multirow[t]{2}{*}{ Mollusca } & Gastropoda & Neogastropod & Planorbidae & - & - & - & - & - & 3.38 \\
\hline & & & Physidae & - & - & - & - & - & 81.38 \\
\hline \multirow[t]{3}{*}{ Annelida } & Oligochaeta & Opisthopora & Tubificidae & - & - & - & 0.42 & 0.11 & 99.63 \\
\hline & & & Lumbriculidae & - & - & 0.94 & 0.73 & 0.52 & 0.25 \\
\hline & & & Naididae & 0.31 & 0.11 & - & 0.21 & - & - \\
\hline Annelida & Hirudinea & Gnathobdellida & Erpobdellidae & - & - & - & - & - & 24 \\
\hline \multirow[t]{2}{*}{ Platyhelminthes } & Turbellaria & Seriata & Dugesiidae & - & 0.31 & 1.88 & 1.25 & 0.83 & - \\
\hline & & & Total density & 249.51 & 260.69 & 383.708 & 368.28 & 335.65 & 677.77 \\
\hline
\end{tabular}

Table 6. Selected Bio-indices for 6 sampling stations in Pauh River Cameron Highlands

\begin{tabular}{lllllll}
\hline Index & Station 1 & Station 2 & Station 3 & Station 4 & Station 5 & Station 6 \\
\hline Shannon & $2.39 \pm 0.03$ & $2.06 \pm 0.17$ & $1.79 \pm 0.47$ & $1.70 \pm 0.35$ & $1.37 \pm 0.35$ & $0.81 \pm 0.25$ \\
Margalef & $3.76 \pm 0.19$ & $3.25 \pm 0.40$ & $3.13 \pm 0.28$ & $3.45 \pm 0.16$ & $2.85 \pm 0.44$ & $0.70 \pm 0.13$ \\
Pielou & $0.75 \pm 0.03$ & $0.69 \pm 0.06$ & $0.61 \pm 0.18$ & $0.55 \pm 0.13$ & $0.47 \pm 0.13$ & $0.46 \pm 0.13$ \\
BMWP & $140.80 \pm 10.24$ & $127.60 \pm 12.34$ & $121.20 \pm 20.55$ & $138.00 \pm 8.63$ & $111.00 \pm 13.36$ & $13.00 \pm 3.67$ \\
ASPT & $6.03 \pm 0.31$ & $6.54 \pm 0.59$ & $5.97 \pm 0.27$ & $6.07 \pm 0.24$ & $5.95 \pm 0.32$ & $2.25 \pm 0.56$ \\
\hline
\end{tabular}

\section{a. Shanon diversity index}

The result of Shanon diversity index shows that decrease pattern with a reading of $2.39 \pm 0.03$ at station 1 and station $6,0.81 \pm 0.25$. One-way ANOVA analysis shows that there are significant differences between stations ( $\mathrm{P}$ $<0.001$ ) and Tukey test shows station 6 have significant differences with station 1, 2, 3, 4 and 5.

By using Pearson correlation analysis, the Shannon diversity index has been found having a positive correlation with the WQI $(r=0.706, n=29, P<0.01)$. As seen in Figure 3, the Shannon diversity index decreased with the decreased WQI from station 1 to station 6. Moreover, there are significant differences for Shannon diversity index and WQI between monitoring stations 1, 2, 3, 4 and 5 with monitoring station 6 . This was due to different water quality status - class II at station 1 to 5 and Class III water quality at station 6 .

Besides, Pearson correlation analysis also shows that Shannon diversity index has negative relationship with Biochemical Oxygen Demand (BOD) $(r=-0.598, \mathrm{P}<0: 01)$ and ammoniacal nitrogen $\left(\mathrm{NH}_{3}-\mathrm{N}\right)(\mathrm{r}=-0.840$, $\mathrm{P}<0: 01$ ). Based on this result, there is inverse relationship between Shannon diversity index and BOD and $\mathrm{NH}_{3}-\mathrm{N}$. According to Debesh and Kakali (2014), high BOD and $\mathrm{NH}_{3}-\mathrm{N}$ are caused by untreated domestic sewage and agro-based effluent. As shown in Figure 4, good water quality in Station 1, 2, 3, 4 and 5 support various types of macroinvertebrate taxa which do not particularly tolerant to pollution especially the domestic sewage and agro-based effluent. In Station 6, the number of macroinvertebrate taxa is the lowest with only 7 taxa which cause the impairment of Shannon diversity index. There is no Shannon diversity index achieve above 2.5 in this study. Wilhm \& Dorris (1968) stated that the value of the diversity index with value lower than 1.0 is considered highly polluted; 1.0 to 3.0 as slightly polluted, and higher than 4.0 as the water is not contaminated. The result obtained from this study shows that Station 1 to 5 are categorized as slightly polluted and station 6 as contaminated. Macroinvetebrate benthic diversity in station 6 is most likely influenced by the presence of organic pollutants in the river (Flores \& Zafaralla 2012). This is because effluent from settlement, shops and plantation are observed along the river bank at station 6 . 


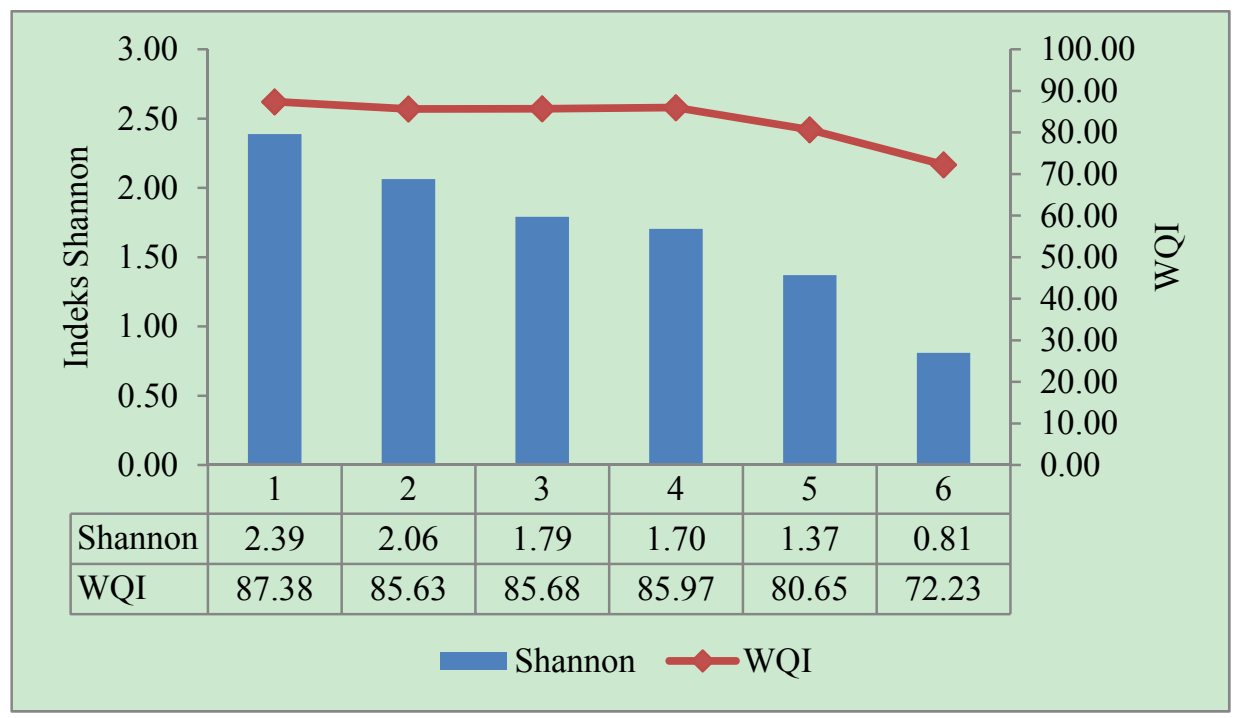

Figure 3. Average of Shannon diversity index and Water Quality Index (WQI) at six sampling stations

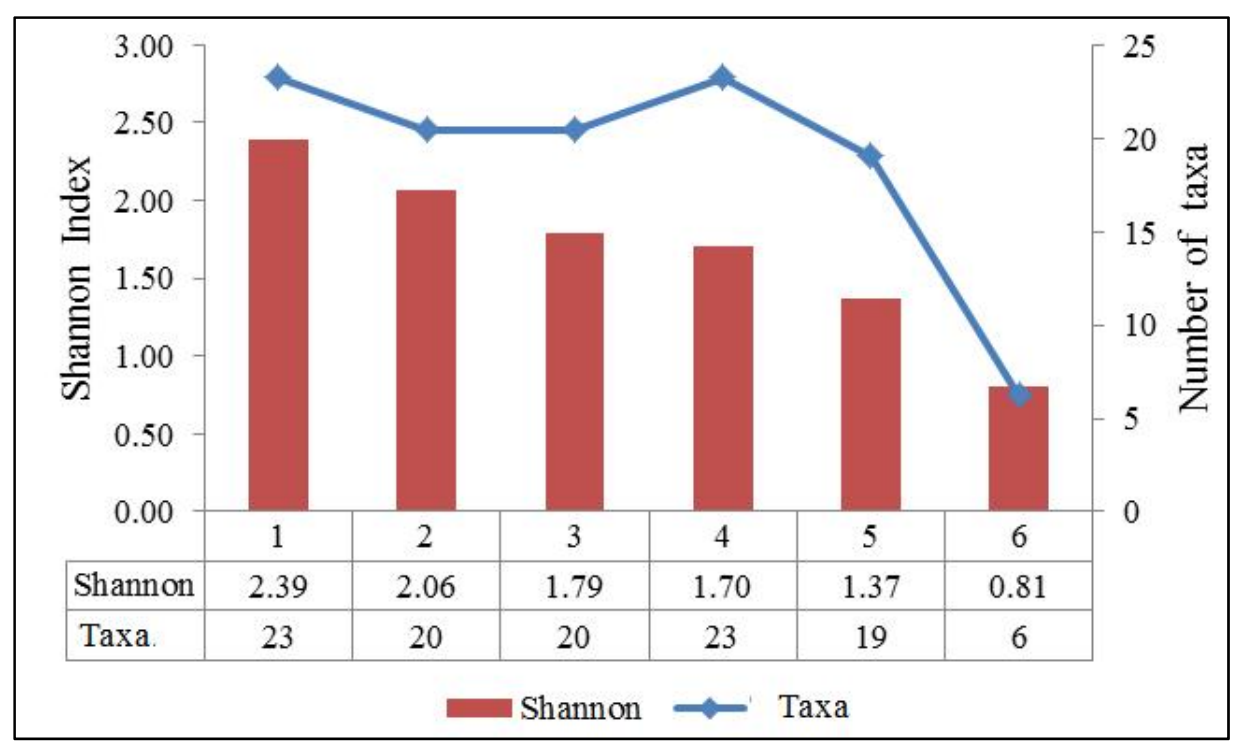

Figure 4. Average of Shannon diversity index and the number of families at six sampling stations

\section{b. Margalef diversity index}

Margalef diversity index shows a decline pattern for 5 monitoring stations except Station 4 (Figure 5); Station 1 recorded the highest value $(3.76 \pm 0.21)$ and Station 6 recorded the lowest value $(0.70 \pm 0.154)$. One-way ANOVA analysis result shows there is significant differences between the stations $(\mathrm{P}<0.001)$.

Based on the analysis result, number of family of benthic macroinvertebrate fauna in station 4 is higher than Station 2, 3,5 and 6. This may due to characteristic of sampling area which is located at high cliff and low human interference. Pearson correlation result shows that Margalef diversity index has positive correlation with WQI $(r=0.57, P<0.01)$. As shown in Figure 6, the Margalef diversity index has been decreased with lower WQI. Besides, the comparison Margalef diversity index and the number of taxa are shown in Figure 5. The figure illustrates that Margalef index increased with higher WQI. It is due to only slightly polluted environment so that both the macroinvertebrate fauna of tolerance and intolerance present in the study area as station 1 to station 5 , which recorded a range of $28-31$ number of taxa. 


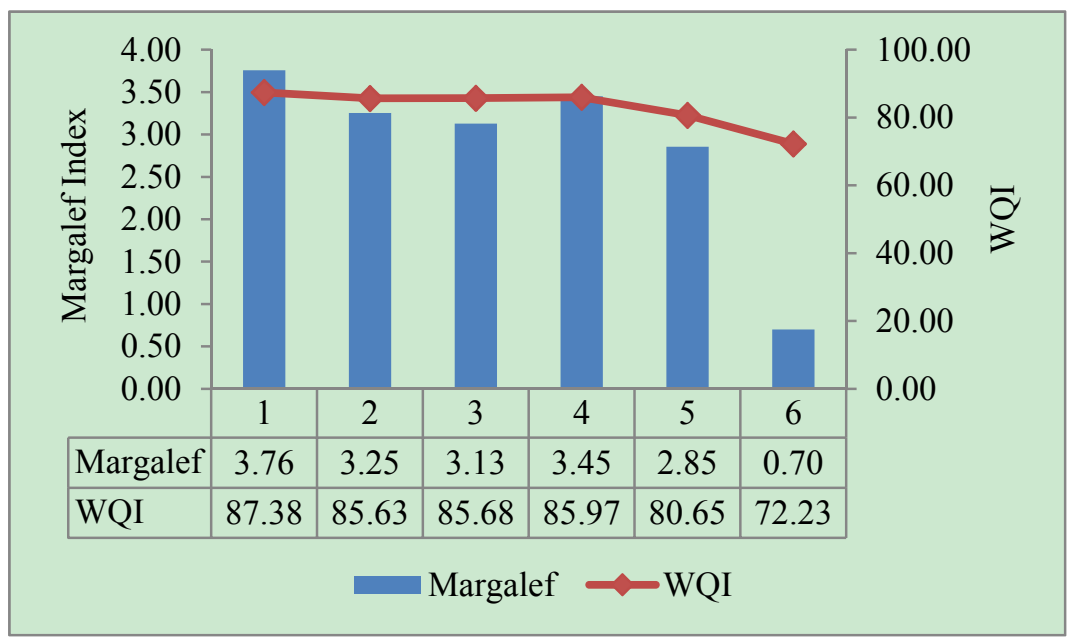

Figure 5. Margalef diversity index and water quality index (WQI) at six sampling stations

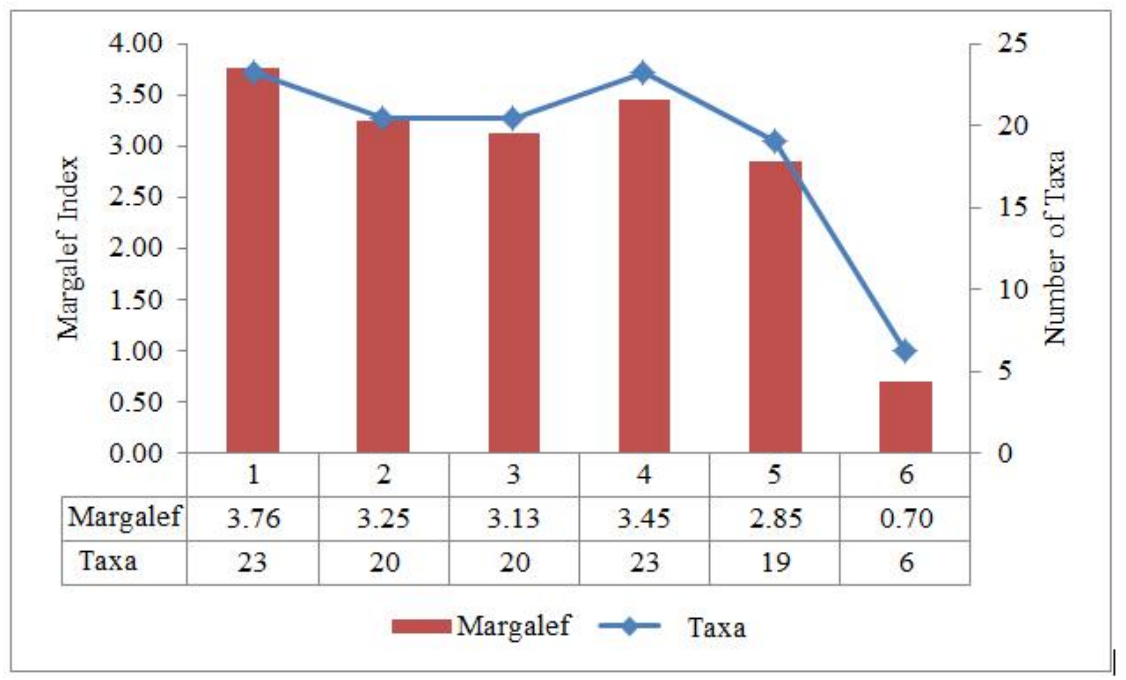

Figure 6. Margalef diversity index and the number of taxa at six sampling stations

According to WQI, Station 6 represents the slightly polluted water (Class III) which only able to support a maximum average of seven taxa of benthic macroinvertebrate fauna. Similar result is found in Shannon diversity index. Pearson correlation analysis indicates that Margalef index has negative relationship with BOD $(r=-0.539$, $\mathrm{P}<0.01)$ and $\mathrm{NH}_{3}-\mathrm{N}(\mathrm{r}=-0.553, \mathrm{P}<0.01)$. Again, it has proven that macroinvetebrate' communities are sensitive to domestic and agro-based pollutants such as fertilizer and herbicide.

\section{c. Pielou Equality Index}

Table 5 shows the value of Pielou equality index at six sampling stations in Pauh River. Station 1 records the $0.75 \pm 0.03$ which is highest value among monitoring station. Nevertheless, Station 6 records the lowest reading which is $0.46 \pm 0.15$. One-way ANOVA analysis shows there is significant differenti among 6 stations $(\mathrm{P}<0.05)$. According to Pearson correlation analysis, it shows no significant correlation between WQI and the Pielou equality index. 


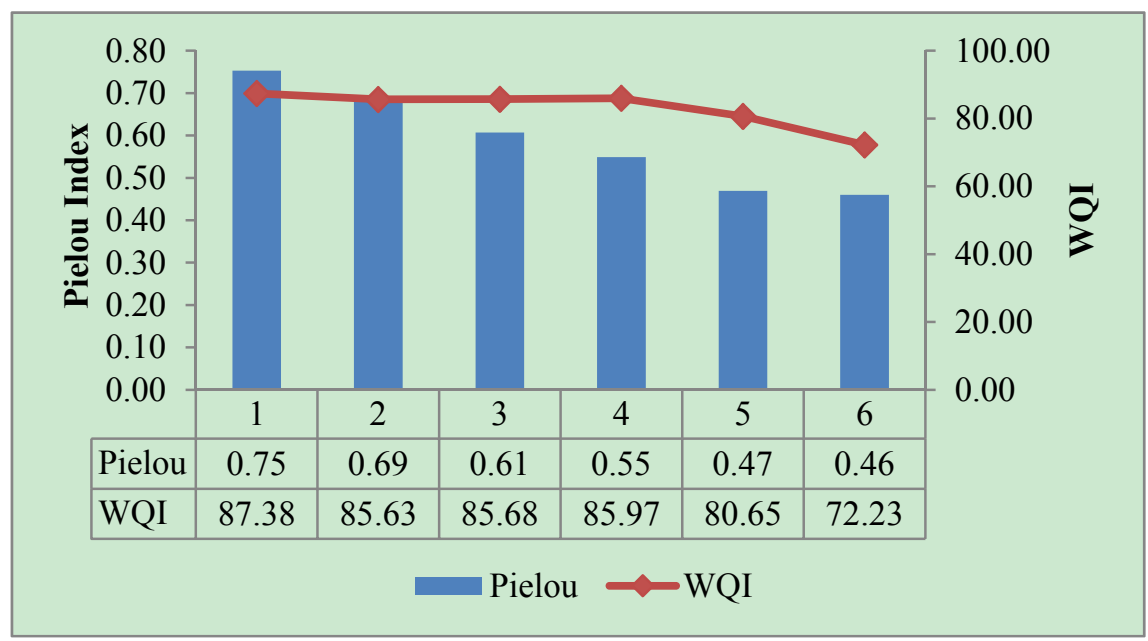

Figure 7. Pielou equality index and water quality index (WQI)

\section{d. Biological Monitoring Working Party (BMWP Score)}

Based on analysis result, Biological Monitoring Working Party (BMWP) score has declined from station 1 to station 6. Station 1 has recorded the highest value which is $140.80 \pm 10: 24$ and Station 6 has recorded lowest value among stations which is $13.00 \pm 0.67$. One-way ANOVA analysis shows there is significant different among these 6 stations $(\mathrm{P}=<0.001)$. Pearson correlation analysis indicates there is positive correction with WQI $(\mathrm{r}=0.756, \mathrm{P}<0.01)$. It means that decreases of WQI will proportionally reduce BMWP score as shown in Figure 8 .

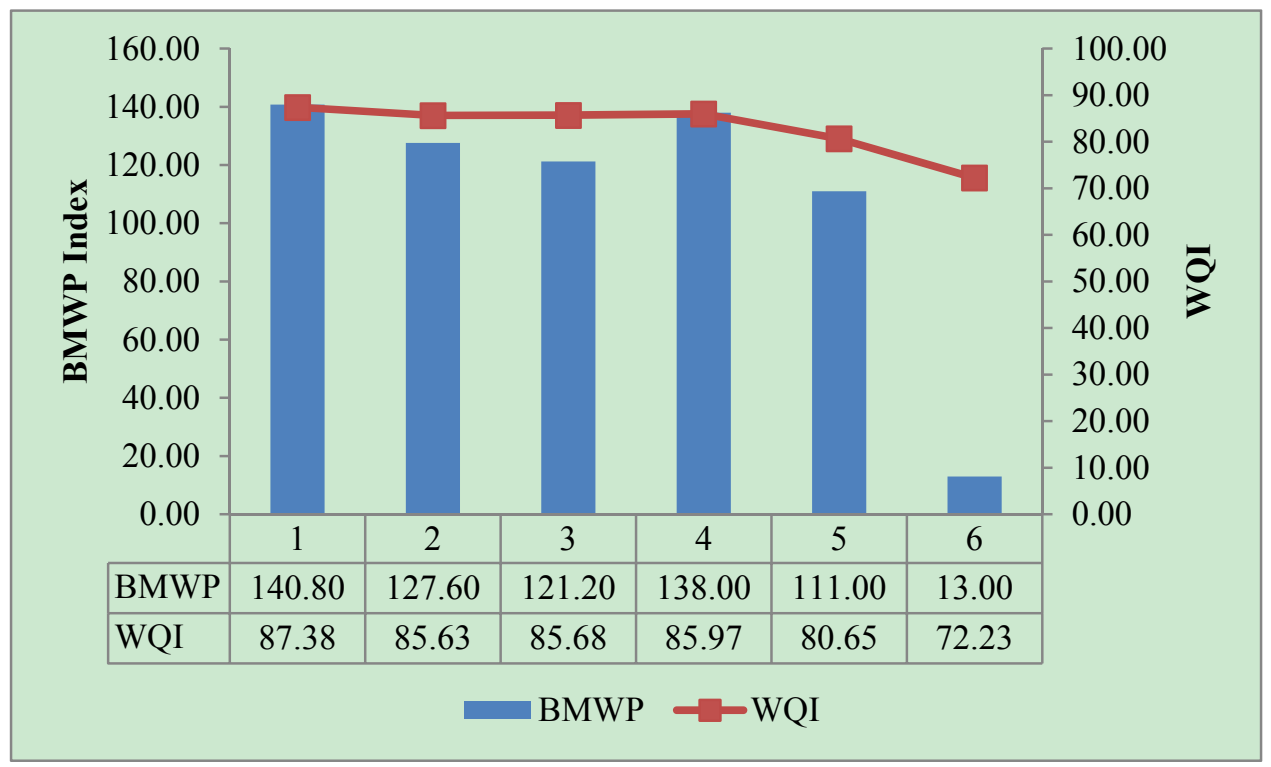

Figure 8. BMWP score and water quality index (WQI)

Station 1, 2, 3, 4 and 5 show a significant different compares with Station 6 for BMWP score and WQI. The range of average BMWP score for station 1 to station 5 is 101-150. BMWP score equals the sum of the tolerance scores of all macroinvertebrate taxa (families) in the sample. According to Cota et al. (2002), higher score of BMWP reflects good water quality.

Figure 9 shows the comparison BMWP index and number of taxa. Stations 2 and 3 have recorded relatively lower BMWP Index if compare to stations 1 and 4. It may due of intensive recreational activities are recorded in Station 2 and 3 e.g recreational activities and water sport which disturbs macroinvetebrate habitat. There are $\underline{29}$ taxa that have been found in Station 2 and 3. At station 4, the number of taxa of benthic macroinvertebrates is $\underline{31}$ 
taxa which slightly higher if compare to Station 2 and 3. It may due to the characteristic of monitoring station as Station 4 is located in steep river bank which free from human interference. As a result, it provides undisturbed habitat to biotic community- benthic macroinvertebrates fauna in Pauh River.

Lowest score of BMWP (13.00) in Station 6 illustrates a reduction scenario in aquatic invertebrates macroinvertebrate fauna diversity (Figure 9). It was due to the polluted water quality in the sampling location. BMWP score has reverse relationship with the ammoniacal-nitrogen $\left(\mathrm{NH}_{3}-\mathrm{N}\right)$ (Pearson correlation analysis $\mathrm{r}=$ $0.89, \mathrm{n}=29, \mathrm{P}<0.01)$. It means that increase of $\mathrm{NH}_{3}-\mathrm{N}$ concentration will reduce BMWP index. This further proves that macroinvertebrates is able to indicate the deterioration of water quality.

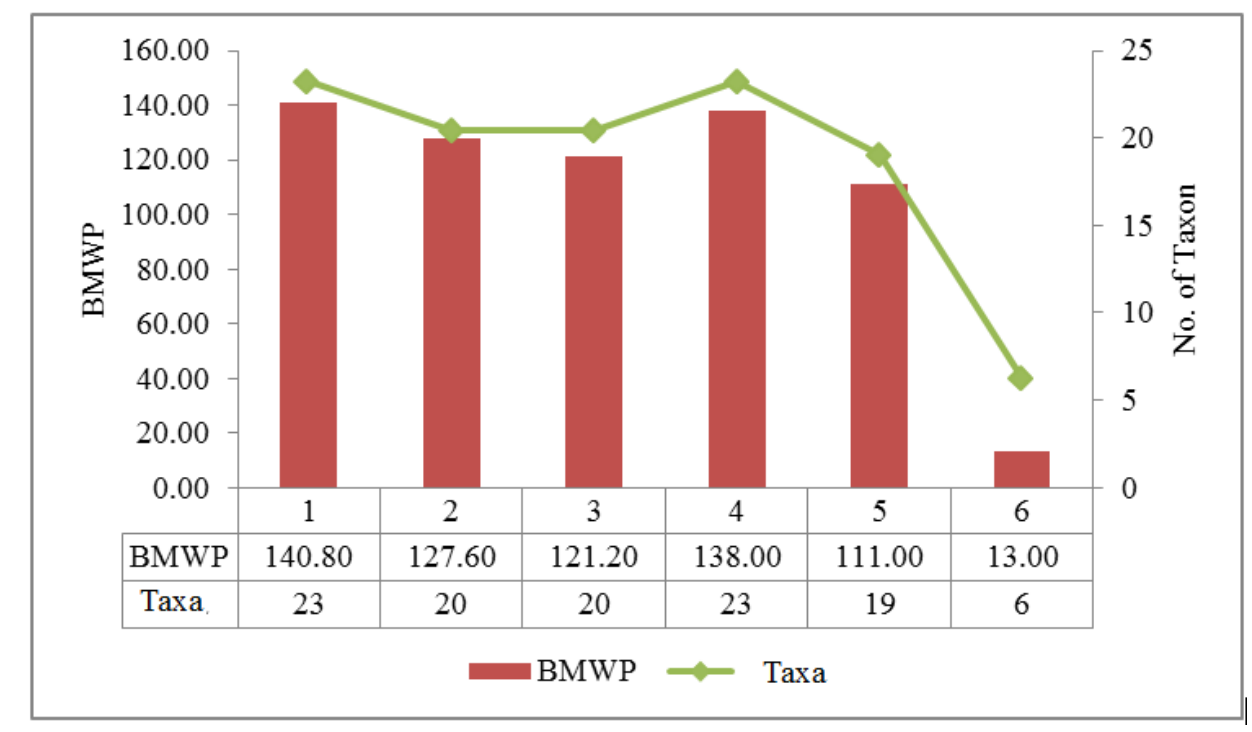

Figure 9. Average BMPW index and taxa for six at six sampling stations

\section{e. Average Score Per Taxa (ASPT)}

ASPT score indicates decrement of ASPT score from Station 1 to Station 6 (Figure 10). Station 2 has recorded the highest score of ASPT 6:54 \pm 0.66 and Station 6 has recorded the lowest score which is $2.25 \pm 0.65$. One-way ANOVA result shows that there is significant differentiate among these 6 stations. Besides, Pearson correlation analysis result shows that ASPT score has positive correlation with WQI $(\mathrm{r}=0.701, \mathrm{n}=29, \mathrm{P}<$ $0.01)$. 


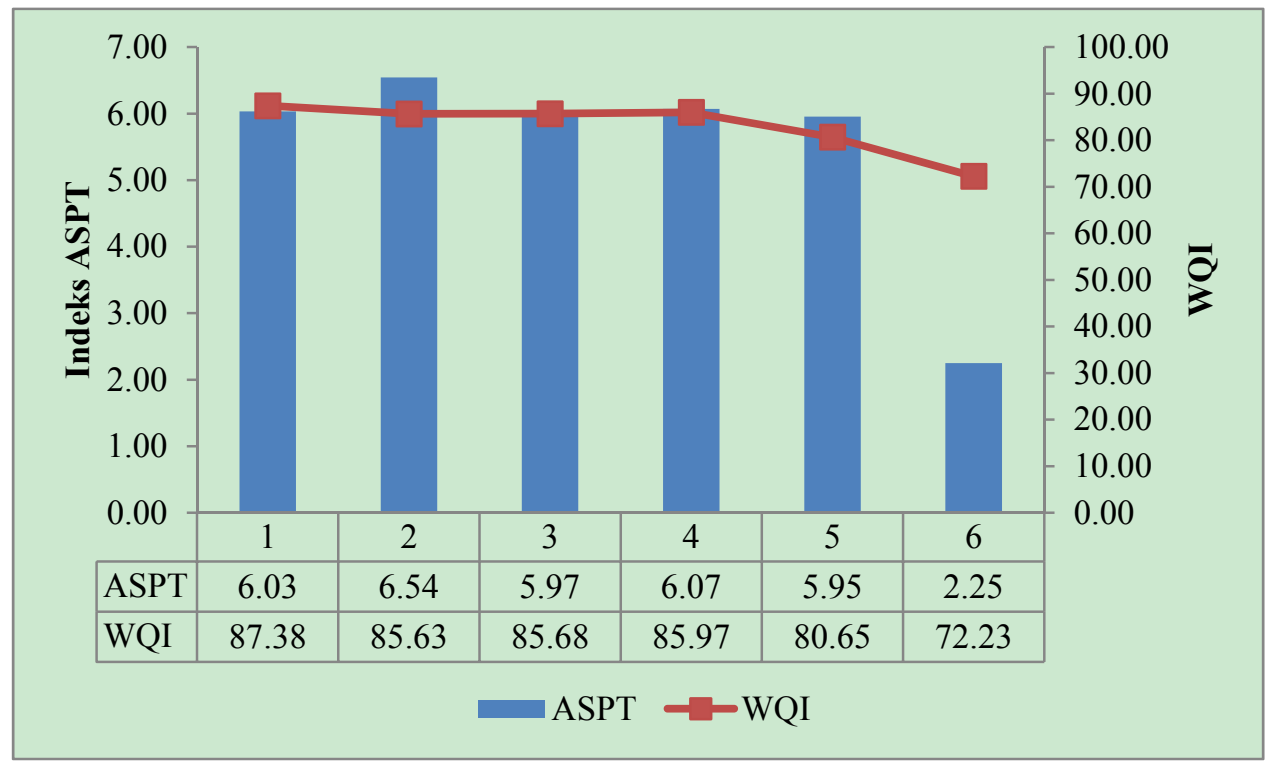

Figures 10. Average score of ASPT and water quality index (WQI)

The range of average ASPT score for station 1 to station 6 is $6.54-2.25$. Station 2 scores highest ASPT with Class II water quality status. Station 6 scores lowest ASPT with lower WQI (72.23) which indicates polluted water at station. There are only 7 taxa of benthic macroinvertebrate fauna found in Station 6. Lowest ASPT scores (2.25) in station 6 shows the decrement of benthic macroinvertebrate fauna taxa which is the consequence of polluted water quality at station 6 as shown in Figure 11.

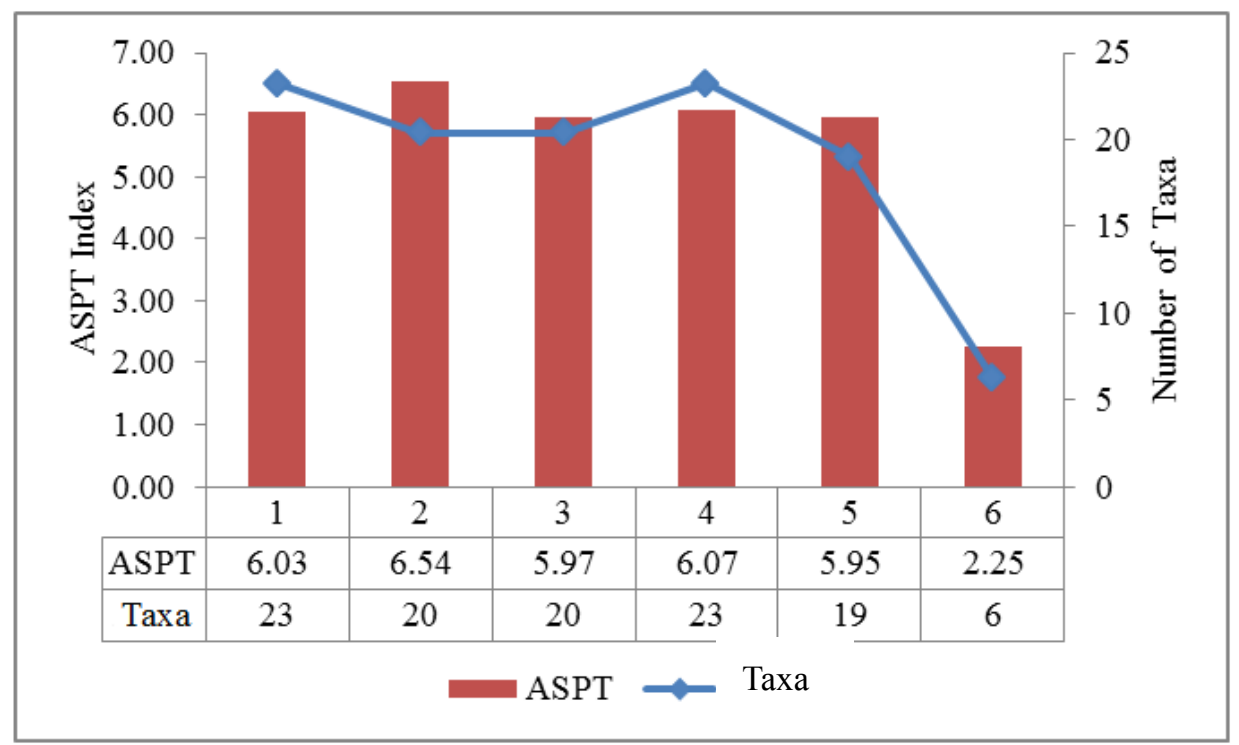

Figure 11. Average index value ASPT and number of taxon for the six sampling stations

\section{Conclusion}

This study demonstrated the approach to evaluate the water quality using macroinvetebrate organism. Combines analysis and assessment of biological parameters to identify physico-chemical water pollution is important for the purpose of monitoring the natural surroundings. Besides being used in the monitoring of the environment, macroinvetebrate were suggested to be used as biological monitoring in recovery and conservation efforts in the future. Chironomiidae and Simuliidae were identified as potential macroinvertbrate organism to use as indicator for water pollution cause by organic pollutants, whereas Hirudinea and Oligochaeta have the potential to be used as indicator for other polluted water. The described results showed that bio-indicator is useful water quality monitoring tool. 


\section{References}

APHA. (1992). Standard Methods for Examination of Water and Wastewater (18th ed.). American Public Health Association (APHA), AWWA \& WPCF, Washington D. C.

APHA. (1998). Standard Methods for Study of Examination of Water and Wastewater (20th ed.). American Public Health Association (APHA), AWWA \& WPCF, Washington.

Azrina, M. Z., Yap, C. K., Ismail, A. R., Ismail, A., \& Tan, S. G. (2006). Anthropogenic impacts on the distribution and biodiversity of benthic macroinvertebrates and water quality of the Langat River, Peninsular Malaysia. Ecotoxicol Environ l Saf., 64, 337-347. http://dx.doi.org/10.1016/j.ecoenv.2005.04.003

Buckup, L., Bueno, A. A. P., Bond-Buckup, G., Casagrande, M., \& Majolo, F. (2007). The benthic fauna of highland stream in southern Brazil: composition, diversity and structure. Revista Brasileira de Zoologica, 24(2), 294-301. http://dx.doi.org/10.1590/S0101-81752007000200005

Cao, Y., Bark, A. W., \& Williams, W. P. (1997). Analyzing benthic macroinvertebrate community changes along a pollution gradient: A framework for the development of biotic indices. Wat. Res., 31, 884-892. http://dx.doi.org/10.1016/S0043-1354(96)00322-3

Cota, L., Goulart, M., Moreno, P., \& Callisto, M. (2002). Rapid assessment of river water quality using an adapted BMWP index: A practical tool to evaluate ecosystem health. Verh. Internat. Verein. Limnol., 28, $1-4$.

Debesh Chakraborty, Kakali Mukhopadhyay. (2014). Water Pollution and Abatement Policy in India: A study from an economic perspective. Springer, New York. http://dx.doi.org/10.1007/978-94-017-8929-5

Department of Environment Malaysia, DOE. (2007). "Malaysia Environmental Quality Report 2006”, In : Chapter 3: River Water Quality. Putrajaya.

Department of Survey and Mapping. (2002). Map of Pahang State. 1:250,000. Kuantan, Malaysia.

Dinakaran, S., \& Anbalagan, S. (2007). Antropogenic impacts on aquatic insects in six streams of south Western Ghats. Journal of Science, 7(37), 1536-2442. http://dx.doi.org/10.1673/031.007.3701

Engel, S. R., \& Voshell, J. R. Jr. (2002). Volunteer biological monitoring: Can it accurately assess the ecological condition of streams? American Entomologist, 48(3), 164-177. http://dx.doi.org/10.1093/ae/48.3.164

Flores, M. J. L., \& Zafaralla, M. T. (2012). Macroinvertebrate composition, diversity and richness in relation to the water quality status of Mananga River, Cebu, Philippines. Philippine Scinece Letter, 5(2), 103-113.

Food and Agriculture Organization (FAO). (n. d.). Peninsular Malaysia Map. Retrieved October 8, 2014, from http://www.fao.org/docrep/field/009/ag160e/AG160E04.gif

Gasim, M. B., Sahid, I., Toriman, E., Pereira, J. J., Mokhtar, M., \& Abdullah, M. P. (2009). Integrated Water Resources Management and Pollution Sources in Cameron Highlands, Pahang, Malaysia. American-Eurasian J. Agric. \& Environ. Sci., 5(6), 725-732.

Hamed Yazdia, Nematollah Jaafarzadeh, \& Banafsheh Zahraie. (2014). Relationship between benthic macroinvertebrate bio-indices and physicochemical parameters of water: a tool for water resources managers. Journal of Environmental Health Science and Engineering. 10:12(1), 30. http://dx.doi.org/10.1186/2052-336X-12-30

Ismail, B. S., Ngan, C. K., Cheah, U. B., \& Wan Abdullah, W. Y. (2004). Leaching potential of pesticides in a vegetable farm in the Cameron Highlands, Malaysia. Bull. Environ. Contam. Toxicol., 72, 836-843. http://dx.doi.org/10.1007/s00128-004-0320-5

Karanth, K. R. (1987). Groundwater Assessment Development and Management. McGraw-Hill Publishing, New Delhi.

Kopciuch, R. G., Berecka, B., Bartoszewicz, J., \& Buszewski, B. (2004). Some considerations about bioindicators in environmental monitoring. Polish. Journal of Environmental Studies, 13, 453-462.

Krenkel, P. A., \& Novotny, V. (1980). Water Quality Management. Academic Press Inc., New York.

Kumaran, S., \& Ainuddin, A. N. (2006). Forest, Water and Climate of Cameron Highlands. In N. W. Chan (Ed.), Cameron Highlands: Issues and Challenges in Sustainable Development. Universiti Sains Malaysia.

Kusza, I. C. (2005). Comparing modified biological monitoring working party score system and several biological indices based on macroinvertebrates for water-quality assessment. Limonologica, 35, 169-176. 
http://dx.doi.org/10.1016/j.limno.2005.05.003

Latha, C., \& Thanga, V. S. G. (2010). Macroinvertebrate diversity of Veli and Ladinamkulam Lakes, South Kerala, India. J Environ Biol., 547, 543-547.

Nemati Varnosfaderany, M., Ebrahimi, E., Mirghaffary, N., \& Safyanian, A. (2010). Biological assessment of the Zayandeh Rud River, Iran, using benthic macroinvertebrates. Limnol. 40, 226-232. http://dx.doi.org/10.1016/j.limno.2009.10.002

Ngan, C. K., Cheah, U. B., Wan Abdullah, W. Y., Lim, K. P., \& Ismail, B. S. (2005). Fate of chlorothalonil, chlorpyrifos and profenofos in a vegetable farm in Cameron Highlands, Malaysia. Water, Air, and Soil Pollution Focus, 5, 125-136. http://dx.doi.org/10.1007/s11267-005-7408-8

Ogleni, N, Topal B (2011). Water quality assessment of the Mudurnu River, Turkey, using biotic indices. Water Resources Management. 25(11), 2487-2508. http://dx.doi.org/10.1007/s11269-011-9822-1

Revenga, C., Campbell, I., Abell, R., de Villiers, P., \& Bryer, M. (2005). Prospects for monitoring freshwater ecosystems towards the 2010 targets. Phil. Trans. R. Soc. B, 360, 397-413. http://dx.doi.org/10.1098/rstb.2004.1595

Swaminathan, M. S. (2003). Bio-diversity: An effective safety net against environmental pollution. Environmental Pollution, 126, 287-291. http://dx.doi.org/10.1016/S0269-7491(03)00241-0

Tan, K. W. (2010). Evaluation of social perception on water issues in Cameron Highlands (Malaysia) by Principle Factor Analysis. J. Environmental Science and Engineering, 4(4), 45-52.

Wan Abdullah, W. Y., Aminuddin, B. Y., \& Zulkifli, M. (2005). Modelling pesticide and nutrient transport in the Cameron Highlands, Malaysia agro-ecosystems. Water, Air, and Soil Pollution Focus, 5, 115-123. http://dx.doi.org/10.1007/s11267-005-7407-9

Wilhm, J. L., \& Dorris, T. C. (1968). Biological parameters of water quality criteria. Bioscience, 18, 477-481. http://dx.doi.org/10.2307/1294272

\section{Copyrights}

Copyright for this article is retained by the author(s), with first publication rights granted to the journal.

This is an open-access article distributed under the terms and conditions of the Creative Commons Attribution license (http://creativecommons.org/licenses/by/3.0/). 